\title{
Influence of Histidine Administration on Ammonia and Amino Acid Metabolism: A Review
}

\author{
Milan HOLEČEK ${ }^{1}$ \\ ${ }^{1}$ Department of Physiology, Charles University, Faculty of Medicine in Hradec Králové, Czech \\ Republic
}

Received February 5, 2020

Accepted April 29, 2020

Epub Ahead of Print June 25, 2020

\begin{abstract}
Summary
Histidine (HIS) is an essential amino acid investigated for therapy of various diseases, used for tissue protection in transplantation and cardiac surgery, and as a supplement to increase muscle performance. The data presented in the review show that HIS administration may increase ammonia and affect the level of several amino acids. The most common are increased levels of alanine, glutamine, and glutamate and decreased levels of glycine and branched-chain amino acids (BCAA, valine, leucine, and isoleucine). The suggested pathogenic mechanisms include increased flux of HIS through HIS degradation pathway (increases in ammonia and glutamate), increased ammonia detoxification to glutamine and exchange of the BCAA with glutamine via L-transporter system in muscles (increase in glutamine and decrease in BCAA), and tetrahydrofolate depletion (decrease in glycine). Increased alanine concentration is explained by enhanced synthesis in extrahepatic tissues and impaired transamination in the liver. Increased ammonia and glutamine and decreased BCAA levels in HIS-treated subjects indicate that HIS supplementation is inappropriate in patients with liver injury. The studies investigating the possibilities to elevate carnosine ( $\beta$-alanyl-L-histidine) content in muscles show positive effects of $\beta$-alanine and inconsistent effects of HIS supplementation. Several studies demonstrate HIS depletion due to enhanced availability of methionine, glutamine, or $\beta$-alanine.
\end{abstract}

\section{Key words}

Histidine supplementation • HTK solution • Carnosine • Betaalanine - Ammonia • Glutamine • Branched-chain amino acids • Bretschneider's solution

\section{Corresponding author}

Milan Holeček, Charles University, Faculty of Medicine in Hradec Králové, Šimkova 870, 50003 Hradec Králové, Czech Republic. E-mail: holecek@lfhk.cuni.cz

\section{Introduction}

L-Histidine (HIS) and HIS-containing dipeptides (HCD), particularly carnosine, have been investigated for possible use in prevention and therapy of several disorders, such as Parkinson and Alzheimer diseases, metabolic syndrome, dermatitis, ulcers, and inflammatory bowel disease (Feng et al. 2013, Hisatsune et al. 2016, Baraniuk et al. 2013, Tan et al. 2017). Large doses of HIS supplements are used by people who believe that daily HIS consumption ameliorates feeling of fatigue, improves cognitive functions, and enhances muscle performance (Sasahara et al. 2015, Suzuki et al. 2006, Hill et al. 2007, Cornelli 2010). Large amounts of HIS are administered in cardiac surgery as a HIS-Tryptophan-Ketoglutarate (HTK) solution (Custodiol ${ }^{\circledR}$ HTK or Bretschneider's solution) for induction of cardiac arrest and myocardial protection (Edelman et al. 2013). A volume of $\sim 1.61$ of cardioplegic solution containing $198 \mathrm{mM}$ HIS is infused causing an increase in plasma HIS concentration from $\sim 70 \mu \mathrm{M}$ to $\sim 20,000 \mu \mathrm{M}$ immediately after induction of cardioplegia (Teloh et al. 2016).

Despite frequent use of HIS and HCD in several indications, there is not enough information about HIS metabolism in context with metabolism of other amino acids. Only limited data exist in regard to the consequences of high HIS levels on concentrations of ammonia and other amino acids. HIS contains 3 atoms of nitrogen, which should appear as ammonia when HIS is catabolized (Fig. 1) and exert adverse effects on the function of several tissues, particularly of the liver and the kidneys. Little is also known as to how enhanced HIS intake affects the 
availability of carnosine, an efficient intracellular $\mathrm{pH}$ buffer in muscles (Abe 2000). An understanding of the effects of high HIS concentrations can also be applied in the exploration of metabolic changes associated with diseases. In the atherosclerosis risk in communities (ARIC) follow-up study, high serum HIS was negatively related to the risk of coronary heart disease among African- and European- Americans (Yu et al. 2015).

The main objective of the review is to explore the studies reporting the consequences of high HIS concentrations on the level and metabolism of other amino acids and to give some answers regarding the possible side effects of HIS administration. The second aim is to show the influences of other amino acids on HIS metabolism.

\section{Effects of HIS administration on other amino acids}

Studies reporting effects of high HIS concentrations on other amino acids

The data from human and animal studies indicate that the most common findings in HIS-loaded (Table 1) and HIS-supplemented subjects (Table 2) are increased levels of alanine (ALA), glutamate (GLU), and glutamine (GLN) and decreased levels of glycine (GLY) and branched-chain amino acids (BCAA, valine, leucine, and isoleucine). In the following sections of the article, an attempt is made to clarify the pathogenesis of these alterations.

Table 1. Effects of acute load of a large dose of HIS on amino acid, ammonia, and ATP concentrations

\begin{tabular}{|c|c|c|}
\hline Study design & Main findings & Reference \\
\hline $\begin{array}{l}\text { Humans, antegrade } \\
\text { cardioplegia (HTK } \\
\text { solution, } 1.6 \mathrm{~L})\end{array}$ & $\begin{array}{l}\text { Plasma: } \uparrow \text { HIS, GLU, ALA, GLN, Asp, and Asn } \\
\text { Urine: } \uparrow \text { HIS, GLU, and GLN } \\
\text { (samples collected during surgery) }\end{array}$ & Teloh et al. 2016 \\
\hline $\begin{array}{l}\text { Normal human subjects, } \\
\text { HIS load (15 g orally) }\end{array}$ & $\begin{array}{l}\text { Plasma at } 1 \text { or } 2 \text { hours: } \\
\uparrow \text { HIS, GLY, ALA, Tau, Thr, Ser, Lys, and Arg } \\
\downarrow \text { BCAA, Tyr, Phe, and Orn }\end{array}$ & Holton 1968 \\
\hline $\begin{array}{l}\text { Normal human subjects, } \\
\text { HIS load ( } 75 \mathrm{mg} / \mathrm{kg} \text { body } \\
\text { weight, intravenously) }\end{array}$ & $\begin{array}{l}\text { Plasma at } 1 \text { hour: } \\
\uparrow \text { in most amino acids, especially ALA } \\
\text { Plasma at } 3 \text { hours: } \\
\downarrow \text { in nearly all amino acids }\end{array}$ & $\begin{array}{l}\text { Hamblin and } \\
\text { Holton } 1972\end{array}$ \\
\hline $\begin{array}{l}\text { Rats, HIS load } \\
\text { (800 } \text { (mol/rat, } \\
\text { intravenously) }\end{array}$ & $\begin{array}{l}\text { At } 2 \text { hours: } \\
\text { Plasma: } \uparrow \text { HIS, ALA, GLU, GLN, Asp, urea, ammonia; } \downarrow \text { GLY } \\
\text { Urine: } \uparrow \text { urea, ammonia, and all amino acids } \\
\text { Liver: } \uparrow \text { HIS and GLU; } \downarrow \text { GLY, GLN, Tau, and ATP } \\
\text { Muscles: } \uparrow \text { HIS; } \downarrow \text { GLY, Ser, and ATP } \\
\text { At } 24 \text { hours: } \\
\text { Plasma: } \downarrow \text { BCAA } \\
\text { Muscles: } \uparrow \text { ammonia; } \downarrow \text { BCAA and ATP }\end{array}$ & $\begin{array}{l}\text { Holeček and } \\
\text { Vodeničarovová } \\
2019\end{array}$ \\
\hline $\begin{array}{l}\text { Rats, HIS load ( } 0.5 \mathrm{or} \\
1.0 \mathrm{~g} / \mathrm{kg} \text { body weight, } \\
\text { intraperitoneally) }\end{array}$ & $\begin{array}{l}\text { At } 1 \text { hour: } \\
\text { Plasma: } \uparrow \text { HIS, ALA, and GLN } \\
\text { Brain: } \uparrow \text { HIS, ALA, and GLN; } \downarrow \text { BCAA, MET, Tyr, and Phe }\end{array}$ & $\begin{array}{l}\text { Tyfield and } \\
\text { Holton } 1975\end{array}$ \\
\hline
\end{tabular}

Amino acid abbreviations in capital letters indicate the amino acids specifically discussed in the article.

Pathogenesis of increased GLU and decreased GLY levels - role of the liver

In the liver, HIS administration increases the flux of HIS through HIS degradation pathway leading to
GLU formation. Enhanced GLU production could also be due to hepatic glutaminase activated by increased ammonia level (Verhoeven et al. 1983). The formed GLU can be utilized by different pathways (Fig. 1). In the 
periportal zone of the liver lobule it may be converted to $\alpha-K G$ and ammonia by glutamate dehydrogenase. In perivenous zone of the lobule, which contains GLN synthetase and acts as a scavenger for the ammonia that escaped urea synthesis in periportal zone, GLU can be used for GLN synthesis. The studies examining the effects of dietary GLU demonstrated that significant amounts of GLU might be released by the liver to the blood (Cynober 2018). Hence, it may be suggested that in HIS-treated subjects, the liver enhances the release of
GLU that escaped GLU dehydrogenase and GLN synthetase reactions, resulting in increased GLU concentrations in blood plasma. Most of the GLU released from the liver is removed by muscles, which use it for the synthesis of ALA and GLN (Cynober 2018, Klin et al. 2010). Increased GLN synthesis by perivenous hepatocytes probably plays a role in increased GLN concentrations in the blood, however, the skeletal muscle is more important source of GLN (discussed below).

Table 2. Effects of chronic HIS consumption on amino acid concentrations

\begin{tabular}{|c|c|c|}
\hline Study design & Main findings & Reference \\
\hline $\begin{array}{l}\text { Rats, HIS-enriched diet ( } 7 \% \text { or } \\
14 \% \text { HIS) for } 8 \text { days }\end{array}$ & $\begin{array}{l}\text { Plasma: } \uparrow \text { HIS; } \downarrow \text { BCAA, GLY, and Thr } \\
\text { Brain: } \uparrow \text { HIS and GLN; } \downarrow \text { Val and Thr }\end{array}$ & $\begin{array}{l}\text { Tyfield and Holton } \\
1975\end{array}$ \\
\hline $\begin{array}{l}\text { Cats, HIS-enriched diets ( } 0.6 \text {, } \\
1.0 \text {, and } 1.4 \%) \text { for } 2 \text { weeks }\end{array}$ & Plasma: $\uparrow$ HIS and GLN; $\downarrow$ GLY & Martin et al. 2012 \\
\hline $\begin{array}{l}\text { Rats, HIS in drinking water }(0.5 \\
\text { or } 2.0 \mathrm{~g} / \mathrm{L}) \text { for } 4 \text { weeks }\end{array}$ & $\begin{array}{l}\text { Plasma: } \uparrow \text { HIS, ALA, GLU, Pro, Asp, and ammonia } \\
\text { Liver: } \uparrow \text { HIS and ALA } \\
\quad \downarrow \text { GLY, MET, and Asp } \\
\text { Muscles: } \uparrow \text { HIS, ALA, GLN }\end{array}$ & $\begin{array}{l}\text { Holeček and } \\
\text { Vodeničarovová } 2020\end{array}$ \\
\hline $\begin{array}{l}\text { Obese women, HIS (4 g/day) for } \\
12 \text { weeks }\end{array}$ & $\begin{aligned} \text { Plasma: } & \uparrow \text { HIS, ALA, GLN, GLY, Lys, Asp } \\
& \downarrow \text { Leu, Ile, Phe, Trp, and Tau }\end{aligned}$ & Du et al. 2017 \\
\hline
\end{tabular}

Amino acid abbreviations in capital letters indicate the amino acids specifically discussed in the article.

It has been suggested that increased HIS degradation depletes tetrahydrofolate (THF) required for conversion of formiminoglutamate (FIGLU) to GLU and thus influences folate-dependent metabolic pathways of several amino acids, particularly GLY, methionine (MET), and serine (Arakawa et al. 1972). MeléndezHevia et al. (2009) proved that THF-dependent synthesis of GLY from serine accounts for more than $85 \%$ of the total. Hence, the decrease in GLY concentrations reported in several studies examining the effects of HIS administration can be explained by THF depletion.

\section{Pathogenesis of increased GLN and decreased BCAA} levels in the blood - role of ammonia and muscles

An increased ammonia concentration in the blood in HIS-loaded and HIS-supplemented subjects (Holeček and Vodeničarovová 2019 and 2020) should originate from incomplete detoxification of ammonia produced from HIS catabolism in the liver to urea and increased HIS deamination to urocanate in the skin. Under these conditions, in skeletal muscle, alternative pathway of ammonia detoxification to GLN is activated (Fig. 2, left side). A supply of GLU, the second substrate for GLN synthetase reaction, is secured by the increased influx of GLU originating from HIS catabolism in the liver.

Most of the GLN synthesized in muscles is released to the blood by the exchange with the BCAA via L-transport system (Meier et al. 2002), resulting in increased GLN and decreased BCAA levels in the blood. GLN released from muscles can be effectively utilized by several tissues and exert favourable effects on gut integrity, the immune system, and protein balance (Newsholme and Hardy 1997). Hence, it may be suggested that some positive effects of HIS administration are mediated by GLN and that HIS supplementation is an alternative way to achieve GLN supplementation. The increased GLN concentrations in HIS-treated subjects may also be partially due to increased release by the liver of GLN synthesized by perivenous hepatocytes.

It should be emphasized that alterations in 
muscles associated with increased ammonia detoxification to GLN after HIS administration are substantially different from those induced by hyperammonaemia in liver cirrhosis and urea cycle disorders (Fig. 2, right side). In the later conditions, ammonia detoxification to GLN causes intracellular depletion of GLU, drains $\alpha-K G$ from tricarboxylic acid (TCA) cycle (cataplerosis) resulting in mitochondrial dysfunction, and increases catabolism of the BCAA, which act as a donor of nitrogen to $\alpha-K G$ to form GLU
(Wagenmakers 1990, Davuluri et al. 2016, Holeček and Vodeničarovová 2018). Furthermore, because of the liver injury, ammonia originating from GLN catabolism is not effectively detoxified to urea, thus, ammonia may exert its toxic effects on the brain and could be detoxified to GLN in the muscles. As a result, a vicious cycle is activated in which an enhanced ammonia concentration activates synthesis of GLN leading to its subsequent catabolism and an increased ammonia level in the blood (Holeček 2014).

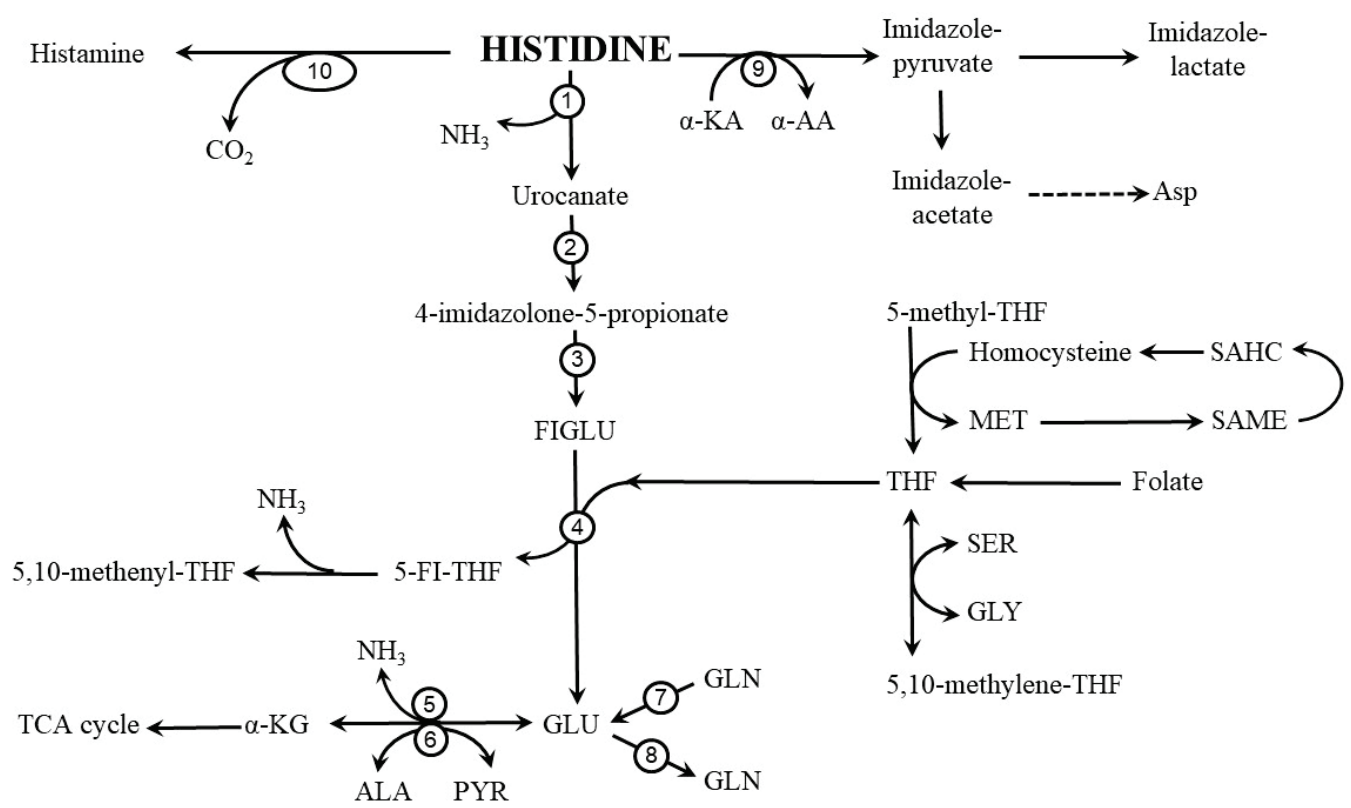

Fig. 1. Pathways of HIS catabolism. The main pathway of HIS catabolism begins with deamination catalyzed by histidase to urocanate and leads through 4-imidazolone-5-propionate and FIGLU to GLU. Alternative pathways of HIS catabolism include transamination to imidazolepyruvate and decarboxylation to histamine. 1) histidase, 2) urocanase, 3) imidazolone propionate hydrolase, 4) glutamate formimino transferase, 5) glutamate dehydrogenase, 6) alanine aminotransferase, 7) glutaminase, 8) glutamine synthetase, 9) histidine aminotransferase, 10) histidine decarboxylase. ALA, alanine, Asp, aspartic acid, FIGLU, formiminoglutamate, GLN, glutamine, GLU, glutamic acid, GLY, glycine, PYR, pyruvate, SAHC, S-adenosylhomocysteine, SAME, S-adenosylmethionine, SER, serine, THF, tetrahydrofolate, TCA cycle, tricarboxylic acid cycle, a-AA, a-amino acid, a-KA, a-keto acid, a-KG, a-ketoglutarate
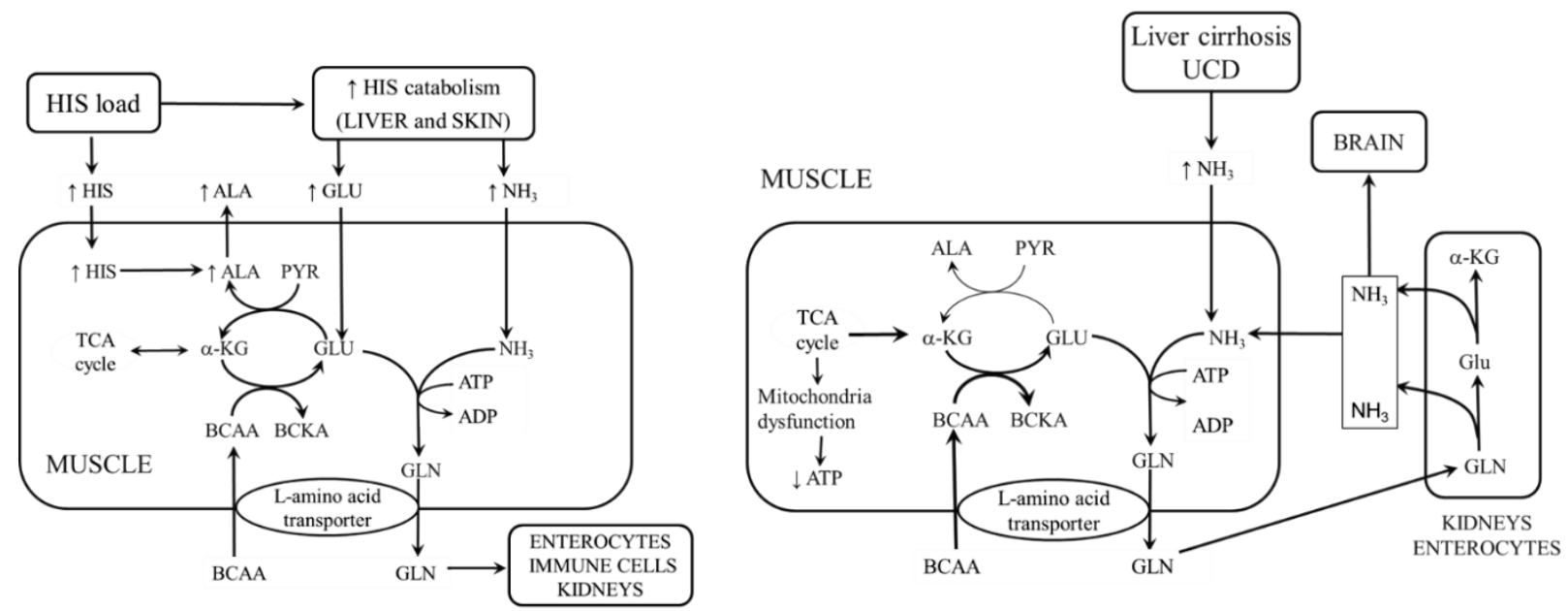

Fig. 2. Consequences of ammonia detoxification to GLN in muscles after HIS administration (left side) and in liver injury (right side). ALA, alanine, BCAA, branched-chain amino acids, BCKA, branched-chain keto acids, GLU, glutamic acid, GLN, glutamine, HIS, histidine, PYR, pyruvate, TCA cycle, tricarboxylic acid cycle, a-KG, a-ketoglutarate 


\section{Pathogenesis of increased ALA levels}

The pathogenesis of markedly increased ALA levels in blood, muscles, and the liver in HIS-treated subjects is complex. In addition to an increased synthesis of ALA from GLU in muscles (Fig. 2, left side), a significant role in ALA synthesis is played by histidine aminotransferase, the first enzyme of alternative pathway of HIS catabolism (Fig. 1). This enzyme exists in two isoforms (Noguchi et al. 1976). Isoenzyme 1 is expressed only in the liver and is active towards pyruvate and $\alpha$-ketoglutarate. Isoenzyme 2 is expressed in the liver, kidneys, heart, and skeletal muscle and is active only towards pyruvate resulting in ALA formation. Moreover, since the alanine aminotransferase reaction is reversible and near equilibrium, a rise in GLU concentration in the liver would inhibit ALA conversion to pyruvate (Fig. 1). A role in increased ALA concentration may have also ALA synthesis from GLN by enterocytes (Windmueller and Spaeth 1975). Whether or not increased ALA concentrations in HIS-treated subjects should be of concern is not clear.

Effects of altered amino acid transport across cell membranes

Because HIS shares its cellular transporters with other amino acids, an effect of competition may alter the transport of other amino acids and their distribution among tissues. The competition between HIS and other amino acids for transporters has undoubtedly a significant influence during the early phase after loading with a large dose of HIS, as occurs after infusion of HTK solution in cardiac surgery. Increased concentrations of most of the amino acids in blood plasma are observed, along with decreased amino acid concentrations in tissues and remarkably increased urinary loss of most amino acids 1 or 2 hours after the HIS load (Holton 1968, Hamblin and Holton 1972, Holeček and Vodeničarovová 2019).

The competition between HIS and other amino acids for transport seems to play an important role in the brain. Since HIS is transported into the brain principally on the large neutral amino acid (LNAA) carrier (Oldendorf and Szabo 1976, Oldendorf et al. 1988) that also transports aromatic amino acids (AAA, tyrosine, phenylalanine, and tryptophan), decreased transport of AAA may alter the synthesis of several neurotransmitters, particularly serotonin, dopamine, and norepinephrine.

A precipitous rise in serum HIS would increase HIS levels in the brain and its metabolism to histamine. The findings of histamine elevations in brain in
HIS-injected and HIS-consuming rats (Sheiner et al. 1985, Lozeva et al. 2003) led to suggestion that daily HIS consumption ameliorates feeling of fatigue and improves attentiveness (Sasahara et al. 2015). There are reports of positive effects of dried bonito broth, called dashi, that contains high amounts of HIS, on mood in healthy subjects and subjects with fatigue symptoms (Kuroda et al. 2007, Nozawa et al. 2008). However, studies examining the role of a high HIS concentration on maintenance of neurotransmitter pools in the brain are inconclusive, and more rigorous studies are needed to clarify the effect of HIS supplementation on brain functions.

\section{Effects of HIS administration on content of HCD}

HCD found in vertebrates include anserine (beta-alanyl-N1-methylhistidine), carnosine (beta-alanylL-histidine), homocarnosine (gamma-aminobutyryl-Lhistidine), balenine (ophidine, beta-alanyl- $\mathrm{N}_{3}$ methylhistidine), acetyl carnosine (N-acetyl- $\beta$-alanyl-Lhistidine), and carcinine (beta-alanylhistamine). The only HCD synthetized in humans are carnosine and homocarnosine. Carnosine is mainly found in skeletal muscle, while homocarnosine is exclusively present in the brain.

Homocarnosine acts as a source gammaaminobutyric acid (GABA) in specific tracts of CNS (Jackson et al. 1994). Carnosine is a more efficient intracellular $\mathrm{pH}$ buffer and antioxidant than is free HIS (Dahl et al. 1988, Hartman et al. 1990). In accordance with its anaerobic energy delivery in fast-twitch muscles, carnosine and anserine contents are higher in fast-twitch (white) muscles as compared with slow-twitch (red) muscles (Abe 2000, Hill et al. 2007, Holeček and Vodeničarovová 2019). It is assumed that an increase in muscle carnosine content may have some benefits for athletes and elderly, as well as in treating various disorders. Unfortunately, the reports of the effects of HIS supplementation on the level of HCD are not entirely conclusive (Table 3).

\section{Effects of other amino acids on HIS metabolism}

Knowledge of the mechanism how certain amino acid affects the metabolism of other amino acids can contribute to better understanding of the complex 
interconnections of individual amino acids metabolism.

Several articles have demonstrated significant effects of
GLN, MET, and $\beta$-alanine on HIS levels in blood and tissues.

Table 3. Effects of HIS administration on content of HCD

\begin{tabular}{|c|c|c|}
\hline Study design & Main findings & Reference \\
\hline $\begin{array}{l}\text { Rats, HIS-enriched diet ( } 7 \% \text { or } \\
14 \% \text { HIS) for } 8 \text { days. }\end{array}$ & $\uparrow$ homocarnosine (brain) & $\begin{array}{l}\text { Tyfield and Holton } \\
1975\end{array}$ \\
\hline $\begin{array}{l}\text { Rats, HIS-depleted or } \\
\text { HIS-enriched ( } 5 \%) \text { diet for } \\
2 \text { weeks. }\end{array}$ & $\begin{array}{l}\downarrow \text { anserine and carnosine in gastrocnemius muscle } \\
\text { in HIS-depleted animals } \\
\uparrow \text { carnosine and anserine in gastrocnemius muscle } \\
\text { in rats fed a HIS-enriched diet }\end{array}$ & Tamaki et al. 1977 \\
\hline $\begin{array}{l}\text { Humans, HIS }(3.5 \mathrm{~g} / \text { day }), \beta \text {-alanine } \\
(6.0 \mathrm{~g} / \text { day }) \text { or combination, orally } \\
\text { for } 23 \text { days. }\end{array}$ & $\begin{array}{l}\text { No effect in HIS-supplemented subjects. } \\
\uparrow \text { carnosine in m. vastus lateralis after } \beta \text {-alanine or } \\
\text { combined therapy. }\end{array}$ & Blancquaert et al. 2017 \\
\hline $\begin{array}{l}\text { Rats, HIS in drinking water }(0.5 \text { or } \\
2.0 \mathrm{~g} / \mathrm{L}) \text { for } 4 \text { weeks }\end{array}$ & $\begin{array}{l}\downarrow \text { anserine in soleus muscle but not in extensor } \\
\text { digitorum longus and tibialis muscles } \\
\text { No effect on carnosine }\end{array}$ & $\begin{array}{l}\text { Holeček and } \\
\text { Vodeničarovová } 2020\end{array}$ \\
\hline $\begin{array}{l}\text { Rats, HIS load ( } 800 \mu \mathrm{mol} \text { HIS/rat } \\
\text { intravenously). }\end{array}$ & $\begin{array}{l}\uparrow \text { carnosine in soleus but not in extensor digitorum } \\
\text { longus muscles at } 24 \text { hours }\end{array}$ & $\begin{array}{l}\text { Holeček and } \\
\text { Vodeničarovová } 2019\end{array}$ \\
\hline
\end{tabular}

\section{Effects of GLN}

Consumption of a GLN-enriched diet by rats for 3 months increased HIS and GLN concentrations in the blood plasma and muscles, whereas the level of other amino acids decreased or were unchanged (Holeček 2011). The effect was not observed in the gut, liver, and kidneys. In another studies, performed under in vitro conditions, the HIS concentration decreased in muscles incubated in GLN-enriched medium (Holeček et al. 2015) and increased in muscles incubated in GLN-deficient medium (Holeček and Šišpera 2014).

These findings might be explained by influence of GLN on the amino acid transport system N, which has a narrow substrate specificity of GLN, HIS, and asparagine (Leonardi et al. 1988). Competition between GLN and HIS for the transporter may explain the enhanced blood HIS concentrations in subjects consuming a GLN-enriched diet, the decreased HIS concentration in muscles incubated in medium with a high GLN concentration, and the increased HIS concentration in muscles incubated in GLN-deficient medium. A similar system (designated system $\mathrm{N}^{\mathrm{m}}$ ) is involved in the release of GLN from muscle (Rennie et al. 1986) and might be responsible for increases in HIS concentration in the muscles of animals chronically fed a GLN-enriched diet.

\section{Effects of MET}

Fell and Stele (1983) conducted several experiments to examine the effects of MET on HIS metabolism in rats. An experiment in which rats were fed a MET-enriched diet for at least 10 days revealed a $49 \%$ reduction of plasma HIS and an $80 \%$ reduction in urinary excretion of FIGLU. When a $100 \mathrm{mg}$ HIS load was given on day 5, urinary FIGLU excretion was $83 \%$ lower in MET-supplemented animals relative to controls. The experiment using labeled HIS showed that MET-supplemented animals oxidized $21 \%$ more HIS than controls, although histidase and urocanase activities were unaffected. A study by other authors has shown that addition of MET, S-adenosylmethionine, homocysteine, or S-adenosylhomocysteine to isolated rat hepatocytes increased HIS oxidation two- to fourfold (Billings et al. 1981). All these studies showed that MET supplementation may activate HIS catabolism by increasing the availability of THF generated by the MET cycle during conversion of homocysteine to MET (Fig. 1). 


\section{Effects of $\beta$-alanine}

$\beta$-Alanine is considered to be the rate-limiting precursor of carnosine synthesis in humans (Blancquaert et al. 2017) and several studies have demonstrated that $\beta$-alanine supplementation increases intracellular carnosine concentration and subsequently improves highintensity exercise performance (Harris et al. 2006, Varanoske et al. 2017, Blancquaert et al. 2017). Therefore, chronic oral $\beta$-alanine supplementation is becoming a popular ergogenic strategy.

However, the consequences of $\beta$-alanine supplementation on HIS metabolism are not completely clear. Blancquaert et al. (2017) showed in humans a substantial HIS decline $(\sim 30 \%)$ in muscles and plasma after 23 days of $\beta$-alanine supplementation ( $6 \mathrm{~g} /$ day) and hypothesized that increased intake of $\beta$-alanine gradually depletes HIS via a failure of dietary intake to match the increasing use of HIS for carnosine synthesis. In another, methodologically similar study, $\beta$-alanine supplementation did not reduce HIS in muscles (Varanoske et al. 2017). The authors speculated that the discrepancy between their study and that of Blancquaret is due to the differences in dietary HIS intake between American and Belgian population. Obviously, further studies are needed to determine whether $\beta$-alanine supplementation requires a concomitant increase in HIS intake.

\section{Conclusions}

1) The data from human and animal studies show marked alterations in some amino acid concentrations in HIS-loaded and HIS-supplemented subjects. The most common are increased ALA, GLU, and GLN and decreased GLY and BCAA levels in blood plasma. These findings seem to be due to increased HIS flux through HIS degradation pathway (increases in ammonia and GLU), increased GLN synthesis in muscles and subsequent BCAA/GLN exchange through muscle cell membranes (increase in GLN and decrease in BCAA), and THF depletion (decrease in GLY). High levels of ALA are explained by increased activity of HIS transferase in several tissues and impaired ALA transamination in the liver due to increased GLU availability.

2) Increased ammonia and GLN and decreased BCAA levels in HIS-treated subjects indicate that HIS supplementation is inappropriate in patients with liver injury (GLN can be catabolized to ammonia, decreased BCAA levels have adverse effect on protein balance and mental function in patients with hepatic encephalopathy).

3) The studies investigating the possibilities to elevate carnosine content in muscles show positive effect of $\beta$-alanine and inconsistent effects of HIS supplementation.

4) Several studies demonstrated HIS depletion as a consequence of enhanced availability of MET, GLN, or $\beta$-alanine.

\section{Conflict of Interest}

There is no conflict of interest.

\section{Acknowledgements}

Supported by the programme PROGRES Q40/02.

\begin{abstract}
Abbreviations
ALA, alanine; AAA, aromatic amino acids; BCAA, branched-chain amino acids (valine, leucine, and isoleucine), FIGLU, formiminoglutamate; GLN, glutamine; GLU, glutamic acid; HCD, histidinecontaining dipeptides; HIS, histidine; HTK solution, histidine-tryptophan-ketoglutarate solution; MET, methionine; THF, tetrahydrofolate; $\alpha$-KG, $\alpha$-ketoglutarate
\end{abstract}

\section{References}

ABE H: Role of histidine-related compounds as intracellular proton buffering constituents in vertebrate muscle. Biochemistry (Mosc) 65: 757-765, 2000.

ARAKAWA T, HONDA Y, YOSHIDA T: Increase in serum folate following on oral histidine load. Tohoku J Exp Med 108: 239-243, 1972. https://doi.org/10.1620/tjem.108.239

BARANIUK JN, EL-AMIN S, COREY R, RAYHAN R, TIMBOL C: Carnosine treatment for gulf war illness: a randomized controlled trial. Glob J Health Sci 5: 69-81, 2013. https://doi.org/10.5539/gjhs.v5n3p69

BILLINGS RE, NOKER PE, TEPHLY TR: The role of methionine in regulating folate-dependent reactions in isolated rat hepatocytes. Arch Biochem Biophys 208: 108-120, 1981. https://doi.org/10.1016/0003-9861(81)90129-6 
BLANCQUAERT L, EVERAERT I, MISSINNE M, BAGUET A, STEGEN S, VOLKAERT A, PETROVIC M, VERVAET C, ACHTEN E, DE MAEYER M, DE HENAUW S, DERAVE W: Effects of histidine and $\beta$-alanine supplementation on human muscle carnosine storage. Med Sci Sports Exerc 49: 602-609, 2017. https://doi.org/10.1249/MSS.0000000000001213

CORNELLI U: Treatment of Alzheimer's disease with a cholinesterase inhibitor combined with antioxidants. Neurodegener Dis 7: 193-202, 2010. https://doi.org/10.1159/000295663

CYNOBER L: Metabolism of dietary glutamate in adults. Ann Nutr Metab 73(S5): 5-14, 2018. https://doi.org/10.1159/000494776

DAHL TA, MIDDEN WR, HARTMAN PE: Some prevalent biomolecules as defences against singlet oxygen damage. Photochem Photobiol 47: 357-362, 1988. https://doi.org/10.1111/j.1751-1097.1988.tb02737.x

DAVULURI G, ALLAWY A, THAPALIYA S, RENNISON JH, SINGH D, KUMAR A, SANDLERS Y, VAN WAGONER DR, FLASK CA, HOPPEL C, KASUMOV T, DASARATHY S: Hyperammonaemiainduced skeletal muscle mitochondrial dysfunction results in cataplerosis and oxidative stress. J Physiol 594: 7341-7360, 2016. https://doi.org/10.1113/JP272796

DU S, SUN S, LIU L, ZHANG Q, GUO F, LI C, FENG R, SUN C: Effects of histidine supplementation on global serum and urine $1 \mathrm{H}$ NMR-based metabolomics and serum amino acid profiles in obese women from a randomized controlled study. J Proteome Res 16: 222130, 2017. https://doi.org/10.1021/acs.jproteome.7b00030

EDELMAN JJ, SECO M, DUNNE B, MATZELLE SJ, MURPHY M, JOSHI P, YAN TD, WILSON MK, BANNON PG, VALLELY MP, PASSAGE J: Custodiol for myocardial protection and preservation: a systematic review. Ann Cardiothorac Surg 2: 717-728, 2013.

FELL D, STEELE RD: Effect of methionine on in vivo histidine metabolism in rats. J Nutr 113: 860-866, 1983. https://doi.org/10.1093/jn/113.4.860

FENG RN, NIU YC, SUN XW, LI Q, ZHAO C, WANG C, GUO FC, SUN CH, LI Y: Histidine supplementation improves insulin resistance through suppressed inflammation in obese women with the metabolic syndrome: a randomised controlled trial. Diabetologia 56: 985-994, 2013. https://doi.org/10.1007/s00125-013-2839-7

HAMBLIN TJ, HOLTON JB: The effect of an intravenous histidine load on the plasma level of other amino acids. Clin Chim Acta 42: 37-41, 1972. https://doi.org/10.1016/0009-8981(72)90372-5

HARRIS RC, TALLON MJ, DUNNETT M, BOOBIS L, COAKLEY J, KIM HJ, FALLOWFIELD JL, HILL CA, SALE C, WISE JA: The absorption of orally supplied beta-alanine and its effect on muscle carnosine synthesis in human vastus lateralis. Amino Acids 30: 279-278, 2006. https://doi.org/10.1007/s00726-006-0299-9

HARTMAN PE, HARTMAN Z, AULT KT: Scavenging of singlet molecular oxygen by imidazole compounds: high and sustained activities of carboxy terminal histidine dipeptides and exceptional activity of imidazole-4-acetic acid. Photochem Photobiol 51: 59-66, 1990. https://doi.org/10.1111/j.1751-1097.1990.tb01684.x

HILL CA, HARRIS RC, KIM HJ, HARRIS BD, SALE C, BOOBIS LH, KIM CK, WISE JA: Influence of beta-alanine supplementation on skeletal muscle carnosine concentrations and high intensity cycling capacity. Amino Acids 32: 225-233, 2007. https://doi.org/10.1007/s00726-006-0364-4

HISATSUNE T, KANEKO J, KURASHIGE H, CAO Y, SATSU H, TOTSUKA M, KATAKURA Y, IMABAYASHI E, MATSUDA H: Effect of anserine/carnosine supplementation on verbal episodic memory in elderly people. J Alzheimers Dis 50: 149-159, 2016. https://doi.org/10.3233/JAD-150767

HOLEČEK M: Adverse effects of chronic intake of glutamine-supplemented diet on amino acid concentrations and protein metabolism in rat: effect of short-term starvation. E Spen Eur E J Clin Nutr Metab 6: e190-196, 2011. https://doi.org/10.1016/j.eclnm.2011.05.002

HOLECEK M: Evidence of a vicious cycle in glutamine synthesis and breakdown in pathogenesis of hepatic encephalopathy-therapeutic perspectives. Metab Brain Dis 29: 9-17, 2014. https://doi.org/10.1007/s11011-0139428-9

HOLECEK M, SISPERA L: Glutamine deficiency in extracellular fluid exerts adverse effects on protein and amino acid metabolism in skeletal muscle of healthy, laparotomized, and septic rats. Amino Acids 46: 1377-1384, 2014. https://doi.org/10.1007/s00726-014-1701-7 
HOLECEK M, SISPERA L, SKALSKA H: Enhanced glutamine availability exerts different effects on protein and amino acid metabolism in skeletal muscle from healthy and septic rats. JPEN J Parenter Enteral Nutr 39: 847-854, 2015. https://doi.org/10.1177/0148607114537832

HOLEČEK M, VODENIČAROVOVÁ M: Effects of branched-chain amino acids on muscles under hyperammonemic conditions. J Physiol Biochem 74: 523-530, 2018. https://doi.org/10.1007/s13105-018-0646-9

HOLEČEK M, VODENIČAROVOVÁ M: Muscle wasting and branched-chain amino acid, alpha-ketoglutarate, and ATP depletion in a rat model of liver cirrhosis. Int $J$ Exp Pathol 99: 274-281, 2018. https://doi.org/10.1111/iep.12299

HOLEČEK M, VODENIČAROVOVÁ M: Effects of histidine supplementation on amino acid metabolism in rats. Physiol Res 69: 99-111, 2020. https://doi.org/10.33549/physiolres.934296

HOLEČEK M, VODENIČAROVOVÁ M: Effects of histidine load on ammonia, amino acid, and adenine nucleotide concentrations in rat. Amino Acids 51: 1667-1680, 2019. https://doi.org/10.1007/s00726-019-02803-5

HOLTON JB: The effect of a histidine load on plasma levels and renal clearances of other amino acids. Clin Chim Acta 21: 241-245, 1968. https://doi.org/10.1016/0009-8981(68)90133-2

JACKSON MC1, SCOLLARD DM, MACK RJ, LENNEY JF: Localization of a novel pathway for the liberation of GABA in the human CNS. Brain Res Bull 33: 379-385, 1994. https://doi.org/10.1016/0361-9230(94)90280-1

KLIN Y, ZLOTNIK A, BOYKO M, OHAYON S, SHAPIRA Y, TEICHBERG V: Distribution of radiolabeled l-glutamate and d-aspartate from blood into peripheral tissues in naive rats: significance for brain neuroprotection. Biochem Biophys Res Commun 399: 694-698, 2010. https://doi.org/10.1016/j.bbrc.2010.07.144

KURODA M, ISHIZAKI T, MARUYAMA T, TAKATSUKA Y, KUBOKI T: Effect of dried-bonito broth on mental fatigue and mental task performance in subjects with a high fatigue score. Physiol Behav 92: 957-962, 2007. https://doi.org/10.1016/j.physbeh.2007.07.002

LEONARDI MG, COMOLI R, GIORDANA B: Histidine transport in plasma membrane vesicles from rat liver. Pfl Arch Europ J Physiol 411: 328-332, 1988. https://doi.org/10.1007/BF00585123

LOZEVA V, TARHANEN J, ATTILA M, MÄNNISTÖ PT, TUOMISTO L: Brain histamine and histamine H3 receptors following repeated L-histidine administration in rats. Life Sci 73: 1491-503, 2003. https://doi.org/10.1016/S0024-3205(03)00478-8

MARTIN SK, HARMON DL, CONWAY CE, VANZANT ES, MCLEOD KR: Influence of dietary histidine on basophil release, circulating concentration, and urinary excretion of histamine in domestic felines. J Appl Res Vet Med 10: 289-299, 2012.

MEIER C, RISTIC Z, KLAUSER S, VERREY F: Activation of system L heterodimeric amino acid exchangers by intracellular substrates. EMBO J 21: 580-589, 2002. https://doi.org/10.1093/emboj/21.4.580

MELÉNDEZ-HEVIA E, DE PAZ-LUGO P, CORNISH-BOWDEN A, CÁRDENAS ML: A weak link in metabolism: the metabolic capacity for glycine biosynthesis does not satisfy the need for collagen synthesis. J Biosci 34 : 853-872, 2009. https://doi.org/10.1007/s12038-009-0100-9

NEWSHOLEME E, HARDY G: Supplementation of diets with nutritional pharmaceuticals. Nutrition 13: 837-839, 1997. https://doi.org/10.1016/S0899-9007(97)00253-0

NOGUCHI T, MINATOGAWA Y, OKUNO E, KIDO R: Organ distribution of rat histidine-pyruvate aminotransferase isoenzymes. Biochem J 157: 635-641, 1976. https://doi.org/10.1042/bj1570635

NOZAWA Y, ISHIZAKI T, KURODA M, NOGUCHI T: Effect of dried-bonito broth intake on peripheral blood flow, mood, and oxidative stress marker in humans. Physiol Behav 93: 267-273, 2008. https://doi.org/10.1016/j.physbeh.2007.08.021

OLDENDORF WH, SZABO J: Amino acid assignment to one of three blood-brain barrier amino acid carriers. Am J Physiol 230: 94-98, 1976. https://doi.org/10.1152/ajplegacy.1976.230.1.94

OLDENDORF WH, CRANE PD, BRAUN LD, GOSSCHALK EA, DIAMOND JM: pH dependence of histidine affinity for blood-brain barrier carrier transport systems for neutral and cationic amino acids. J Neurochem 50 : 857-861, 1988. https://doi.org/10.1111/j.1471-4159.1988.tb02991.x 
RENNIE MJ, HUNDAL HS, BABIJ P, MACLENNAN P, TAYLOR PM, WATT PW, JEPSON MM, MILLWARD DJ: Characteristics of a glutamine carrier in skeletal muscle have important consequences for nitrogen loss in injury, infection, and chronic disease. Lancet 2(8514): 1008-1012, 1986. https://doi.org/10.1016/S0140$\underline{6736(86) 92617-6}$

SASAHARA I, FUJIMURA N, NOZAWA Y, FURUHATA Y, SATO H: The effect of histidine on mental fatigue and cognitive performance in subjects with high fatigue and sleep disruption scores. Physiol Behav 147: 238-244, 2015. https://doi.org/10.1016/j.physbeh.2015.04.042

SHEINER JB, MORRIS P, ANDERSON GH: Food intake suppression by histidine. Pharmacol Biochem Behav 23: 721-726, 1985. https://doi.org/10.1016/0091-3057(85)90061-9

SUZUKI Y, NAKAO T, MAEMURA H, SATO M, KAMAHARA K, MORIMATSU F, TAKAMATSU K: Carnosine and anserine ingestion enhances contribution of nonbicarbonate buffering. Med Sci Sports Exerc 38: 334-348, 2006.

TAMAKI N, TSUNEMORI F, WAKABAYASHI M, HAMA T: Effect of histidine-free and -excess diets on anserine and carnosine contents in rat gastrocnemius muscle. J Nutr Sci Vitaminol (Tokyo) 23: 331-340, 1977. https://doi.org/10.3177/jnsv.23.331

TAN SP, BROWN SB, GRIFFITHS CE, WELLER RB, GIBBS NK: Feeding filaggrin: effects of 1-histidine supplementation in atopic dermatitis. Clin Cosmet Investig Dermatol 10: 403-411, 2017. https://doi.org/10.2147/CCID.S146760

TELOH JK, DOHLE DS, PETERSEN M, VERHAEGH R, WAACK IN, ROEHRBORN F, JAKOB H, DE GROOT H: Histidine and other amino acids in blood and urine after administration of Bretschneider solution (HTK) for cardioplegic arrest in patients: effects on N-metabolism. Amino Acids 48: 1423-1432, 2016. https://doi.org/10.1007/s00726-016-2195-2

TYFIELD LA, HOLTON JB: The effect of high concentrations of histidine on the level of other amino acids in plasma and brain of the mature rat. J Neurochem 26: 101-105, 1976.

VARANOSKE AN, HOFFMAN JR, CHURCH DD, COKER NA, BAKER KM, DODD SJ, OLIVEIRA LP, DAWSON VL, WANG R, FUKUDA DH, STOUT JR: $\beta$-Alanine supplementation elevates intramuscular carnosine content and attenuates fatigue in men and women similarly but does not change muscle l-histidine content. Nutr Res 48: 16-25, 2017. https://doi.org/10.1016/j.nutres.2017.10.002

VERHOEVEN AJ, VAN IWAARDEN JF, JOSEPH SK, MEIJER AJ: Control of rat-liver glutaminase by ammonia and pH. Eur J Biochem 133: 241-244, 1983. https://doi.org/10.1111/j.1432-1033.1983.tb07454.x

WAGENMAKERS AJ, COAKLEY JH, EDWARDS RH: Metabolism of branched-chain amino acids and ammonia during exercise: clues from McArdle's disease. Int J Sports Med 11: S101-113, 1990. https://doi.org/10.1055/s2007-1024861

WINDMUELLER HG, SPAETH AE: Intestinal metabolism of glutamine and glutamate from the lumen as compared to glutamine from blood. Arch Biochem Biophys 171: 662-672, 1975. https://doi.org/10.1016/00039861(75)90078-8

YU B, LI AH, MUZNY D, VEERARAGHAVAN N, DE VRIES PS, BIS JC, MUSANI SK, ALEXANDER D, MORRISON AC, FRANCO OH, UITTERLINDEN A, HOFMAN A, DEHGHAN A, WILSON JG, PSATY BM, GIBBS R, WEI P, BOERWINKLE E: Association of rare loss-of-function alleles in HAL, serum histidine: levels and incident coronary heart disease. Circ Cardiovasc Genet 8: 351-355, 2015. https://doi.org/10.1161/CIRCGENETICS.114.000697 